\title{
Ginger Extract Ameliorates Renal Damage in High Fat Diet- Induced Obesity in Rats: Biochemical and Ultrastructural Study
}

\author{
El Extracto de Jengibre Mejora el Daño Renal en la Obesidad Inducida por \\ la Dieta Alta en Grasas en Ratas: Estudio Bioquímico y Ultraestructural
}

Mashael Mohammed Bin-Meferij ${ }^{1}$; Attalla Farag El-Kott ${ }^{2,3}$; Ali Abdullah Shati ${ }^{2}$ \& Refaat A. Eid $^{4}$

BIN-MEFERIJ, M. M.; EL-KOTT, A. F. \& SHATI, A. A. \& EID, R. A. Ginger extract ameliorates renal damage in high fat dietinduced obesity in rats: biochemical and ultrastructural study. Int. J. Morphol., 37(2):438-447, 2019.

SUMMARY: Obesity is a modifiable risk factor for the development and progression of kidney disease. Obesity may harm kidneys in individuals without hypertension, diabetes, or pre-existing renal disease. Ginger, Zingiber officinale, has many beneficial pharmaceutical benefits. This study aimed to evaluate the Zingiber officinale protective effect against obesity complications which induced by high fat diet and caused renal dysfunctions. The study period was two months, and the experimental animals' groups were four, 80 Wistar rats were appropriated similarly 20 animals/group: control group; ginger extract group (GE); high-fat diet (HFD); and GE+HFD group. Body and fat weight, creatinine, leptin, TNF- $\alpha$, total antioxidants, renal histopathological and ultrastructure were investigated. Rats in group of HFD showed a significant increase $(\mathrm{P}<0.05)$ in the body and fat weights, creatinine, leptin and TNF- $\alpha$, and significant decrease $(\mathrm{P}<0.05)$ in total antioxidants $(\mathrm{TAS})$. Ginger administration significantly showed the protective restoring the altered parameters. Furthermore, rats co-treated with ginger extract improved the histopathological and ultrastructural renal injury induced by obesity. The study concluded that the ginger extract used could suppress and decrease the renal damage induced by high-fat diet as it possesses potential medicinal values.

KEY WORDS: Ginger extract; Renal histology; High-fat diet (HFD); Obesity; Ultrastructural; Leptin; TNF- $\alpha$

\section{INTRODUCTION}

Obesity is regarded as a surpassing way of life issue in developing countries. It is spreading at a ghastly speed in new world nations because of fast food consumption, causing raised cholesterol levels in blood which in turn can damage blood vessels, nerves and other systems in the body (Kolsi et al., 2017). High-fat diets have been used to produce animal obesity models and related disorders (Kakimoto \& Kowaltowski, 2016). Obesity has reached epidemic proportions in the Unites States (US), making it a significant public health concern, spanning all ages, sexes, ethnicities and races. Information from the National Health and Nutrition Examination Survey (NHANES) gathered in 20056 , utilizing body mass index $\left(\mathrm{BMI} \mathrm{kg} / \mathrm{m}^{2}\right)$ as a measure of overweight or obesity, indicate that of all US adults over the age of 20 years, $34.5 \%$ are overweight, $34.3 \%$ are obese, and $5.9 \%$ are severely obese (Kakimoto \& Kowaltowski). The impact of obesity on chronic renal disease has become increasingly prevalent because of the concurrent increase in the of chronic renal disease and end-stage renal disease (Plantinga et al., 2010). In the US, approximately 19.2 million or $11 \%$ of the American adult population live with chronic renal disease. All kidney diseases combined are the 9th leading cause of death in the US (Chuang et al., 2017). Obesity is a hazard factor for the spread and progression of chronic kidney disease (Câmara et al., 2017). The kidney monitors blood circulations and plays a critical role in blood pressure development. In this way, kidney programming is regarded as a key method for hypertension and renal dysfunction. The increasing spread of obesity has a profound effectiveness on worldwide health, including the risk of kidney disease and hypertension (Tain et al., 2017).

Recently, there has been an expanding interest in exploiting the potential of phytochemicals and plant-derived foods and drinks for restoring the previous metabolic balance. Natural materials use such as ginger has been considered

\footnotetext{
${ }^{1}$ Department of Biology, Princess Nourah bint Abdulrahman University, Riyadh, Saudi Arabia.

${ }^{2}$ Department of Biology, College of Science, King Khalid University, Saudi Arabia.

${ }^{3}$ Department of Zoology, Faculty of Science, Damanhour University, Egypt.

${ }^{4}$ Department of Pathology, College of Medicine, King Khalid University, Abha, Saudi Arabia.
} 
an effective tool for obesity control. Ginger has shown the most significant anti-obesity effects in-vivo and in-vitro studies (Wang et al., 2017). This has been attributed to the fact that ginger appears to impact body weight and fat arrangement through three noteworthy instruments: heat production, increasing breakdown of fat in adipose tissue and reducing the absorption of dietary fat in the intestine (Ebrahimzadeh Attari et al., 2016). It has been observed that oral administration of ginger extract has significantly reduced body weights and serum lipid levels in rats fed with high-fat diet. Furthermore, it was found that ginger extract attenuated high-fat diet (HFD)-induced obesity by increasing skeletal muscle fat catabolism and energy expenditure (Misawa et al., 2015). So, the present examination planned to evaluate some pharmacological impacts of the fluid ginger concentrate on obese rat model and to inspect the potential methods of histological, ultrastructural and biochemical pharmaceutical effects against nephrotoxicity in high fat dietinduced obesity.

\section{MATERIAL AND METHOD}

Animal grouping: This investigation proceeded for two months (Spring 2017), and the example comprised of 80 rats (Sprague-Dawley strain); the normal weight of every rat was around 150-200 g. The rats were separatedinto four equivalent gatherings as takes after: 1) the control group, GI, animals were fed on ad libtum; 2) GE group, GII, animals were fed on ad libtum and ginger extract (95\%) (Nammi et al., 2009); 3) HFD, GIII, were fed on a high-fat diet with ad libtum (Alhashem et al., 2014); and 4) GE+ HFD , GIV, rats were provided with the high-fat eating regimen and orally given the ginger extract. Clinical perceptions were routinely performed, and body weight pick up was estimated during the experimental time. On the final treatment day, all rats were fasted for up to 12 hours and then were anaesthetized with sodium pentobarbital $(60-70 \mathrm{mg} / \mathrm{kg}$, i.p.). For biochemical analysis, blood samples were collected from the animal hearts. All animals were then euthanized, and the kidneys, intra-abdominal fat mass were weighed and extracted. Obesity entanglements and the ginger extract impacts were observed by evaluating the degree of the progression in biochemical parameters in blood, renal histopathological and ultrastructure. The work was approved by the ethics committee of the Faculty of Science at the Princess NourahbintAbdulrahman University, Riyadh, Saudi Arabia.

Biochemical assays: Serum leptin kit was acquired from Abcam (USA; Cat. No. ab100773). Total antioxidants (TAS) in serum was performed using assay kit from Abnova (Taiwan; Cat. No. KA0802). Serum creatinine was determined using colourimetric assay kits from Human Company (Germany). TNF- $\alpha$ was evaluated in renal tissues utilizing ELISA kit from Abnova GmbH, Germany (Catalog No KA0280), where, the optical density was estimated at $620 \mathrm{~nm}$.

Histopathological and Transmission electron microscope procedures: The overnight fasted rats, were sacrificed in the morning under ether anaesthetization and dissected to acquire the kidneys which were fixed in $10 \%$ saline buffered formalin for histological examination and were fixed immediately with $2.5 \%$ glutaraldehyde and $2 \%$ paraformaldehyde for transmission electron microscope investigation (Bancroft \& Gamble, 2008).

Statistical analysis: Data were recorded in terms percentage, frequency, and mean \pm SD. One-way (ANOVA) variance analysis was utilized to tests significance, and when $\mathrm{P}<0.05$ was considered statistically significant (McCormick et al., 2017).

\section{RESULTS}

Biochemical analysis: The average weights of the body and fat of rats feeding on HFD for two months were significantly increased $(\mathrm{P}<0.05)$ in obese rats (group 3$)$ comparison to control rats and other experimental animal groups. Ginger extract (GE) oral management of obese animals (group 4) for two months showed significant decreases $(\mathrm{P}<0.05)$ in body and fat weights when compared to obese rats (Fig. 1). Compared to the baseline measurements, the treatment for two months with ginger water extract resulted in changes in the measured parameters in the different rat groups, especially in group III \&VI. Ginger extract treatment caused significant reduction in creatinine, leptin and TNF- $\alpha$ (respectively, $\mathrm{P}<0.032, \mathrm{P}<0.039$ and $\mathrm{P}<0.05$ ) and significant increase $(\mathrm{P}<0.04)$ in total antioxidant status (Table I).

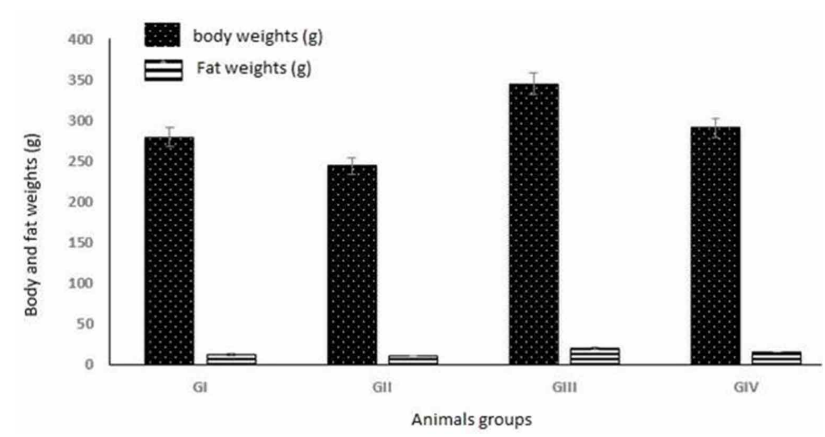

Fig. 1. The body (B.wt) and fat weights (F.wt) in different experimental animals groups. 
Table I. The creatinine, Leptin, TNF- $\alpha$ and TAS levels in different experimental animal's groups

\begin{tabular}{lllll}
\hline \multicolumn{1}{c}{ Biochemical tests } & & \multicolumn{3}{c}{ Animals groups } \\
& GI & GII & GIII & GIV \\
\hline Creatinine $(\mathrm{mg} / \mathrm{dL})$ & $1.09+0.06$ & $1.00+0.07$ & $2.40+0.09^{*}$ & $1.60+0.08$ \\
Leptin $(\mathrm{ng} / \mathrm{ml})$ & $5.69+0.40$ & $4.98+0.5$ & $9.10+1.00^{*}$ & $6.100+0.92$ \\
TNF-_(pg/ml) & $3.00+0.08$ & $2.90+0.07$ & $5.98+0.12^{*}$ & $4.01+0.09$ \\
TAS $(\mathrm{mmol} / \mathrm{L})$ & $1.50+0.08$ & $1.70+0.09$ & $0.80+0.03^{*}$ & $1.58+0.12$ \\
\hline
\end{tabular}
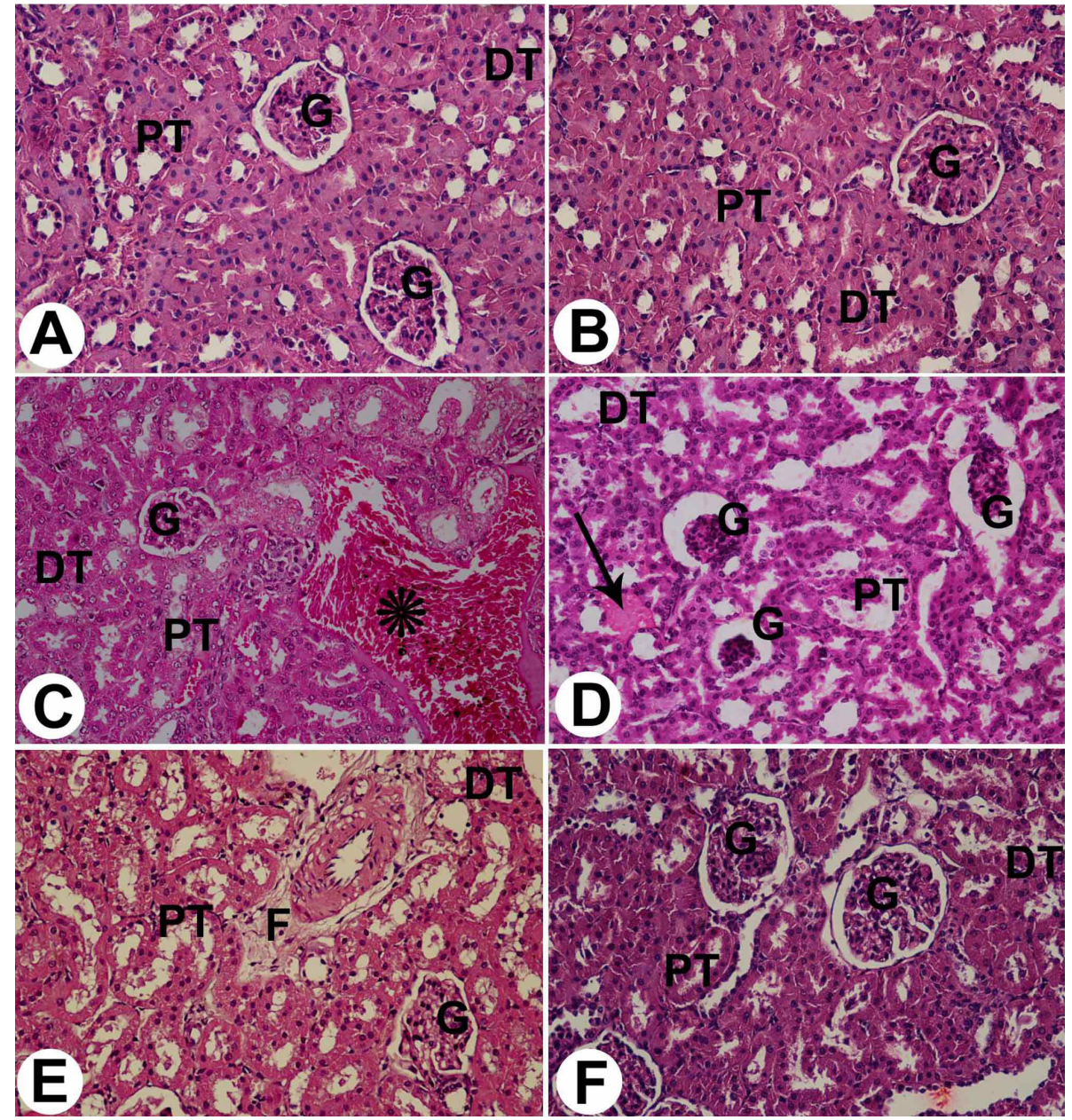

Fig. 2. Representative light micrographs for histopathological changes of kidneys from control, Ginger aqueous extract (GE), high fat diet (HFD) and high fat diet+ Ginger aqueous extract (HFD+GE)-treated rats. X400

A. Control group showing normal glomerular (G) and both proximal (PT) and distal (DT) tubular structures.

B. Ginger aqueous extract (GE) group showing normal glomerular $(\mathrm{G})$ and both proximal (PT) and distal (DT) tubular structures.

C. HFD-treated rats showing minimal changes of the architecture of the renal tissues. Slight swollen of glomerulei $(\mathrm{G})$ and disruption of proximal (PT) and distal (DT) tubules are observed. A haemorrhage area (asterisk) is also seen.

D. HFD-treated rats showing necrotic debris in glomerulei $(\mathrm{G})$ and in both proximal (PT) and distal (DT) tubules. Hyaline casts (arrow) are seen in the tubular lumens.

E. HFD-treated rats showing necrotic debris in glomerulei $(\mathrm{G})$ and in both proximal (PT) and distal (DT) tubules. Also fibrotic tissues (F) are also demonstrated.

F. HFD+GE-treated rats showing improvment in glomerulei $(\mathrm{G})$ and in both proximal (PT) and distal (DT) tubules. They are observed normal structures. 
Histopathological investigation: In the control and GE groups, the Malpighian corpuscles were spherical and each consists of a bunch of blood capillaries called the glomerulus, which surrounded by Bowman's capsule. The urinary space of the malpighian corpuscle continued with the lumen of the proximal tubule. The proximal convoluted tubules were lined with simple cuboidal epithelial cells with acidophilic cytoplasm and exhibit brush margins at their apices. The nuclei of these cells are spherical and centrally located. The distal convoluted tubules were differentiated from the proximal convoluted tubules by the presence of small microvilli, acquiring wider lumen and lined with simple cuboidal epithelial cells (Figs. 2A,B).

In the obesity group, abnormal structures of glomeruli, such as being lobed with shrinkage of some glomeruli forming widen and irregular urinary space was also observed (Fig. 2C). Complete disappearance of some glomeruli and appearance of glomerular debris with ruptured Bowman's capsules which lead to the formation of focal areas of necrosis were seen (Figs. 2D,E). Also, kidney displayed extreme and for all intents and purposes entire
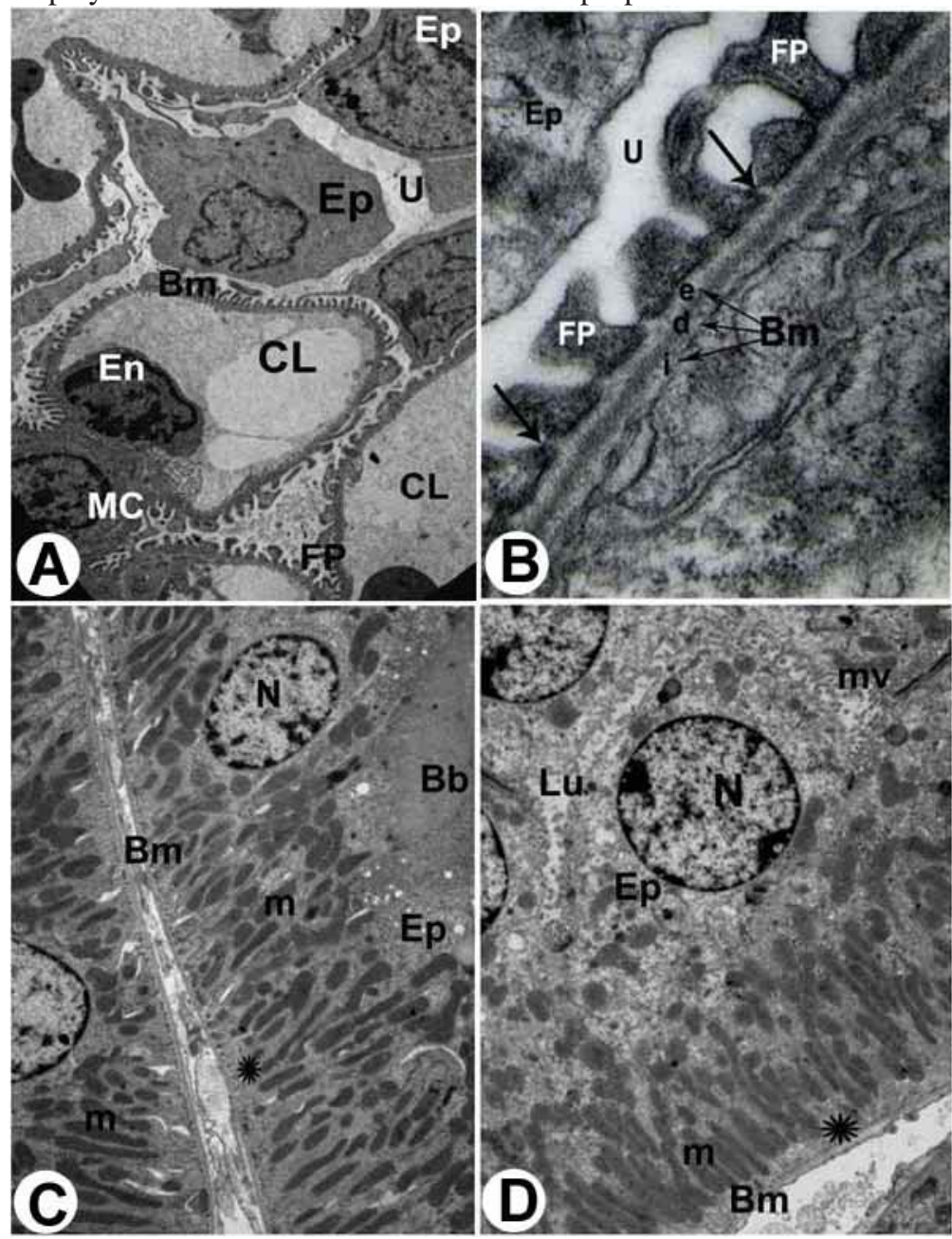

epithelial cell harm and desquamation (flattening epithelium) comparing to the control rats or ginger treated animals group with mononuclear leucocytes infiltration in the interstitial tissue of the renal tubules and the glomerular tufts. Tubular necrosis dilated tubules and fibrotic tissues were shown disruption disrupting the architecture of the renal tissues. The epithelial cells were vacuolated and destructed near their brush margins. However, the degenerated epithelial cells were sloughed as fragments and ousted into the lumen of the renal tubules. Therefore, necrotic debris were shown in the tubule lumens as hyaline casts (Fig. 2D). The glomeruli appeared slightly swollen, and the urinary space of capsules got narrow. Also, slight degenerative changes were seen in some renal tubule as hyaline casts and exfoliated nuclei in their lumen. Pyknotic nuclei were shown in some renal tubules (Figs. 2C,E). The possibility of recovery was evaluated histologically in renal tissues obtained from ginger treated rats, which showed a decrease in the pathological changes as recorded in the previous group (Fig. 2F).

\section{Transmission electron microscope observations.}

Ultrastructural examination of the Malpighian corpuscles of the renal control and ginger extract treated rats revealed that Bowman's capsule visceral layer comprises of podocytes. Each podocyte has a cell body from which extended several primary foot processes. Such cells show electron-dense cytoplasm and elongated oval nuclei. The pedicles of the podocytes are in direct contact with basement membrane of the

Fig. 3. Transmission electron micrographs (TEM) of normal (control) rat's kidney showing:

A. A glomerulus showing some capillary lumina (CL), basement membranes (Bm), endothelium (En), mesangial (MC), visceral cells or podocytes (Ep), foot processes (FP) and urinary spaces (U). X5000

B. Higher magnification displaying the three layers of the glomerular basement membrane (Bm); an inner layer (the lamina rara interna, i), an outer layer (the lamina rara externa, e), and a dense central layer (the lamina dinsa, d), thin diaphragms (arrows), foot processes (FP) and podocyte (Ep). X20000

C. A cross section of a proximal convoluted tubule illustrating cuboidal epithelial cells (Ep) lining the tubule resting on the basement membrane $(\mathrm{Bm})$ and brush margin $(\mathrm{Bb})$ in the tubular lumen $(\mathrm{Lu})$. Note mitochondria $(\mathrm{m})$, nucleus $(\mathrm{N})$ and infolding membranes (asterisk) are also seen. X5000

D. A cross section of a distal convoluted tubule showing simple cuboidal epithelial cells (Ep) with short microvilli (mv) resting on the basement membrane $(\mathrm{Bm})$. Note mitochondria $(\mathrm{m})$, nucleus $(\mathrm{N})$, infolding membranes (asterisk) and tubular lumen $(\mathrm{Lu})$ are also seen. X5000 


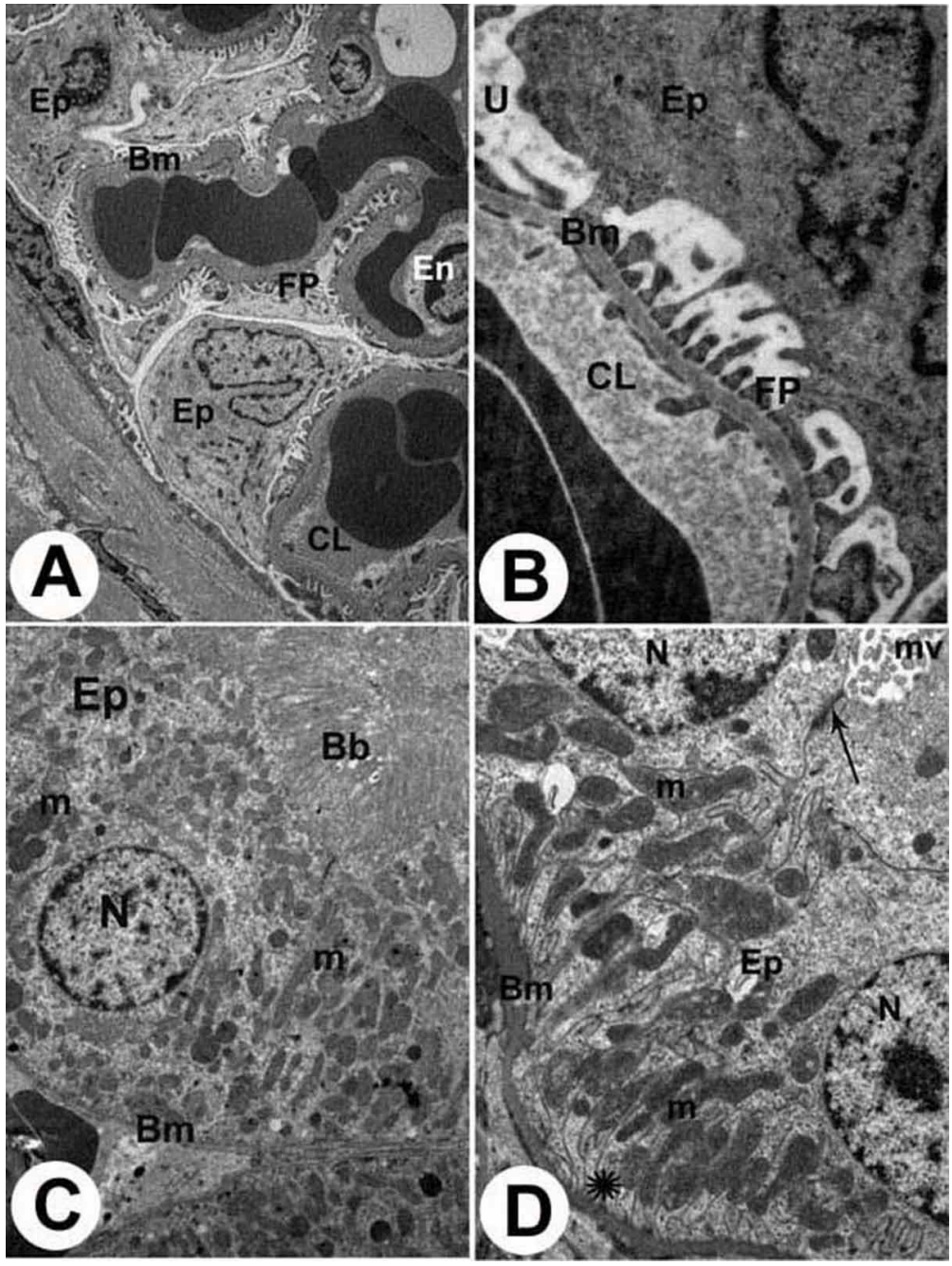

Fig. 4. Transmission electron micrographs (TEM) of ginger-treated rat's kidney showing:

A. Aglomerulus showing some capillary lumina (CL), basement membranes (Bm), endothelium (En), visceral cells or podocytes (Ep) and foot processes (FP). X5000

B. Higher magnification illustrated the glomerular basement membrane $(\mathrm{Bm})$ lining glomerular capillary lumen (CL), foot processes (FP), podocyte (Ep) and urinary space (U). X20000

C. A cross section of a proximal convoluted tubule illustrating cuboidal epithelial cells (Ep) lining the tubule resting on the basement membrane $(\mathrm{Bm})$ and brush margin $(\mathrm{Bb})$ in the tubular lumen $(\mathrm{Lu})$. Note mitochondria $(\mathrm{m})$, nucleus $(\mathrm{N})$ and infolding membranes (asterisk) are also seen. X5000

D. A cross section of a distal convoluted tubule showing simple cuboidal epithelial cells (Ep) with short microvilli (mv) resting on the basement membrane (Bm). Note mitochondria $(\mathrm{m})$, nucleus $(\mathrm{N})$, infolding membranes (asterisk), desmosome (Arrow) and tubular lumen $(\mathrm{Lu})$ are also seen. X5000

glomerular capillary forming the outer layer of the capillary wall; they are interdigitated and delimiting the filtrationslits between them. The glomerulus embodies the mesangial cells that have cytoplasmic extensions and materials; the mesangium (Figs. 3A,B and 4A,B). The proximal convoluted tubule cells have microvilli, contain numerous mitochondria, few lysosomes in their cytoplasm and centrally located spherical nuclei. The basal part of the plasma membrane of these cells exhibits few deep basal infoldings which are closely related to elongated mitochondria that lie in the basal region of such cells (Figs. 3C and $4 \mathrm{C}$ ). The distal convoluted tubule cells exhibit many ultrastructural features in common with the proximal convoluted tubule ones, the most striking difference is that the distal tubules have larger diameters than the proximal ones, and the luminal margin of their lining cells lack the brush margins, but in some distal tubule cells, few cytoplasmic processes are seen (Figs. 3D and 4D).

In obese animals, some glomerular capillaries observed luminal deformity including congestion and clear areas due to the increase in the viscosity of blood plasma as a result of obesity causing difficult blood draw. Podocytes appear abnormal with degenerated or fused (effacement) pedicels (foot process) resting on the irregular thickened basal lamina of capillaries. Obstruction of filtration slits leads to hydrobic cytoplasm. The irregular mesangial cells and wrinkling basement membranes were also sevent with pyknotic nuclei and several lysosomes (Figs. 5A,B). In the obesity-induced rats, cytoplasmic vacuolization and dissolution of some parts of the proximal tubule cells were demonstrated. Several cells revealed loss of brush margin and even break of the cell membrane, with the cytoplasm expelling into the tubular lumen. Also, the lumen of several tubules was filled with cell debris and flocculent material loses basolateral invaginations with distorted mitochondrial cristae and disintegrated basement membrane. Autophagic vacuoles containing remnants of deteriorated cytoplasmic organelles, some lysosomal bodies and swollen rough endoplasmic reticulum profiles were shown (Figs. 5C,D).

The distal tubular cells earned effaced lumen and vacuolated lining epithelium. Cytoplasmic vacuolation with several degenerated areas, damaged mitochondria, pyknotic nuclei, increased number of lysosomes and cellular debris in the lumen were observed. The basal infoldings, appeared shorter embracing some damaged mitochondria (Figs. 5E,F). After treatment with aqueous ginger extract, the improvement was shown but 

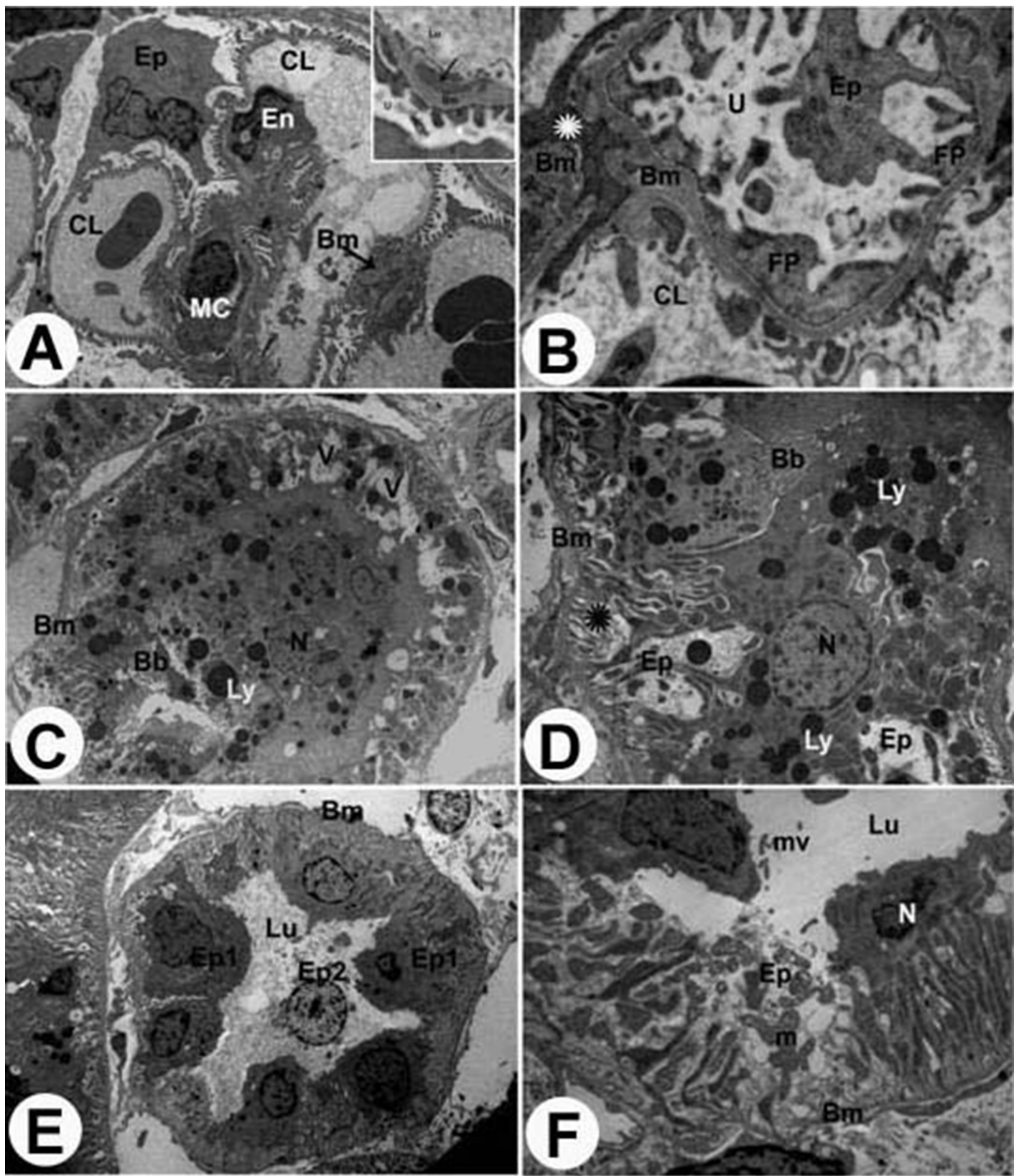

Fig. 5. Transmission electron micrographs (TEM) of obesity rat's kidney showing:

A. A glomerulus showing some capillary lumina (CL) with focal wrinkling basement membranes (Bm) and damaged endothelium (En) and mesangial (MC) cells. Podocytes (Ep) are also seen. X5000.

Insert: Higher magnification of a glomeruler capillary $(\mathrm{CL})$ and basement membrane $(\mathrm{Bm})$ showing focal subendothelial immune deposit (arrow). X20000

B. Higher magnification displaying wrinkling glomerular basement membranes (Bm); fusion foot processes (FP) and electron dense deposits (asterisk). Ep, podocyte and U, urinary space. X20000

C. A cross section of a distorted proximal tubule illustrating increase amounts of lysosomes (Ly) and vacuoles (V) in the epithelial cells (Ep). Damaged brush margin $(\mathrm{Bb})$, irregular nuclei $(\mathrm{N})$ and tubular basement membrane $(\mathrm{Bm})$ are also seen. X3000

D. Higher magnification of a distorted proximal tubule showing damaged cytoplasm and infolding membranes (asterisk) of epithelial cells (Ep) with increased amounts of lysosomes (Ly) and wrinkling tubular basement membrane (Bm). X 5000.

E. A cross section of a disturbed distal tubule shows organelles of a districted epithelial (Ep2) within the lumine (Lu) and edematous epithelial cells (Ep1) resting on the basement membrane (Bm). X3000

F. Higher magnification of a distorted distal tubule showing damaged apical part of epithelial cell (Ep) and microvilli (mv). Megamitochondria $(\mathrm{m})$, irregular pyknotic nuclei $(\mathrm{N})$ wrinkling tubular basement membrane $(\mathrm{Bm})$ are also seen. X 5000 . 
some renal corpuscle still suffered from dramatic changes similar to those observed in obese rat groups such as swelling of the podocyte nucleus, the little degree of effacement, narrow urinary space, mesangial cells with irregular outline nuclei and increased number of lysosomes. A slight improvement was observed in some features, the podocytes appeared with poorly defined organelles, while the nucleus appeared with normal chromatin distribution (Figs. 6A,B). The proximal tubule cells showed the absence of the basolateral invaginations, intact and dense mitochondria, hypertrophied interstitial cells and lysosomal bodies. The apical cell membrane appeared normal with intact brush margin. The nuclei regained their regular appearance. Some cytoplasmic vacuolization and altered electron lucent mitochondria were still observed. However, the observed cytoplasmic changes were milder than those seen in obesity group (Fig. 6C). Otherwise, less normal distal convoluted tubule cells were observed with microvilli and with vacuolated cytoplasm. The cells basal infoldings were extended in the cytoplasm with numerous elongated mitochondria (Fig. 6D).

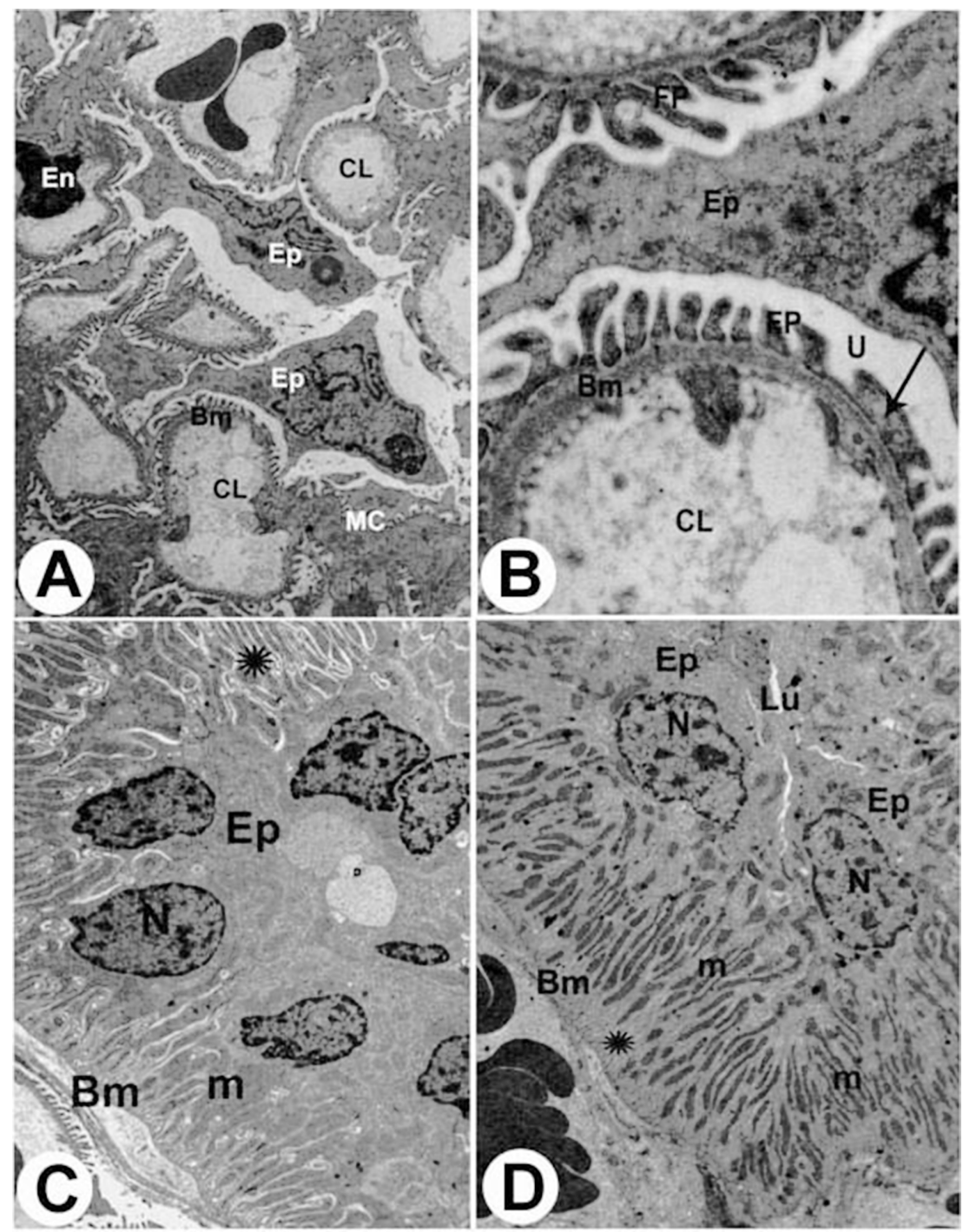

Fig. 6. Transmission electron micrographs (TEM) of obesity rat's kidney treated with ginger (GE) showing:

A. A glomerulus showing some capillary lumina (CL), basement membranes (Bm), endothelium (En) with pyknotic nucleus, mesangial (MC), visceral cells or podocytes (Ep). X5000

B. Higher magnification showing glomerular capillary lumine ( $\mathrm{Lu}$ ) lining by basement membrane (Bm), focal foot processes fusion (arrow) and podocyte (Ep). X20000

C. A cross section of a proximal tubule illustrating epithelial cells (Ep) lining the tubule resting on the basement membrane (Bm). Note intact mitochondria $(\mathrm{m})$ and infolding membranes (asterisk) with irregular-shaped nucleoli $(\mathrm{N})$ are also seen. X5000

D. A cross section of a distal tubule showing epithelial cells (Ep) resting on the basement membrane (Bm). Note intact mitochondria (m) and infolding membranes (asterisk) with irregular-shaped nucleoli $(\mathrm{N})$ are also seen. X5000 


\section{DISCUSSION}

Since the engineered synthetic medications recommended pharmaceutical for treating obesity have numerous backwards symptoms, there is an inducer need to look for elective protected, natural and normal agents from therapeutic plants, herbs and flavors. In the present investigation, overweight has been tentatively incited by bolstering rats HFD from food for two months as indicated by Bhatt et al. (2006). This model of obesity in rats nearly looks like the truth of weight in humans. Keaver et al. (2013) recorded that obesity and overweight are proposed to achieve levels of $85 \%$ and $89 \%$ in males and females separately at 2030. This will increase results the obesity-related spread of diabetes type 2 by $21 \%$, coronary heart disease (CHD) by $97 \%$ and cancers by $61 \%$. Consequently, the direct costs of healthcare will increase significantly. A $5 \%$ reduction in population body mass index (BMI) levels by 2030 are estimated to result in 4495 million decreases in the disbursements on obesity-related direct healthcare over 20 years (Keaver et al.). The dietary ginger is known to goad assimilation and absorption of dietary fat in high-fat-fed situation by enhancing promote the activity of pancreatic lipase and the secretion of bile salts (Prakash \& Srinivasan, 2012). Therefore, this flavor is at the time efficacious in inhibiting body's fats accumulation in the body and hence will help in weight reduction and administration of the body weight (Liu et al., 2016). Ginger intake may significantly $(\mathrm{P}<0.05)$ reduce body and fat weights in feeding rats on HFD when matched to the control rats and ameliorate metabolic profiles through increased glucose transporter type 4 expression, glucose take-up by cells, increased insulin receptors, elevated pancreatic beta cells' functions, and also modifying the adipokines levels (Maharlouei et al., 2018). The ginger Extract renal protective effects against HFDprompted obesity was recorded in the present investigation as there were significant decreases $(\mathrm{P}<0.05)$ in the elevated serum creatinine levels in obese rats co-treated with Ginger Extract. Numerous past examinations explored the helpful defensive impacts of GE against renal harmfulness prompted by different agents with a significant decrease $(\mathrm{P}<0.05)$ in the creatinine levels (Adekunle et al., 2018).Leptin was initially identified by Friedman and colleagues in 1994 as the product of the obese gene (Schanton et al., 2018). A homozygous defect in this gene in obese animals is responsible for their obese phenotype (Hatziri et al., 2018). Leptin is expressed mostly by fat cells which secrete the leptin hormone into the blood. Circulating leptin is transported to the cerebrospinal fluid, where it is available to activate specific receptors and bind on hypothalamic neurons that help adjust energy homeostasis. Plasma leptin concentrations correlate closely with percent body fat, suggesting that leptin is an important signal of fat stores. In the current study, HFD treatment markedly raised the leptin levels. Apparently, these changes may be in part because of upgraded leptin biosynthesis during high fatty diet intake (Ahima \& Flier, 2000). Some studies have scrupulous the association among TNF- $\alpha$ with metabolic diseases. One of the pro-inflammatory cytokines is TNF- $\alpha$ and is a main inducer ofthe transcriptional factor NFkB (Boraska et al., 2010). Increased TNF- $\alpha$ levels are elevated in renal diseases such as glomerulosclerosis, immune complex glomerulonephritis, and aminoglycoside nephritis (Navarro \& Mora-Fernández, 2006). Furthermore, blocking TNF$\alpha$ activity with neutralizing anti-bodies or receptor blocker in a variety of models results in reduced renal injury (Little et al., 2006). These data suggest that TNF- $\alpha$ plays an important role in the pathophysiology of renal disease in obese animals. Where HFD treatment animals markedly increased the TNF- $\alpha$ concentration and ameliorated in ginger extract treatment animals. We have demonstrated that ginger extract could obstruct the raised expression of NFkB in HFDinduced obese animals (Kim et al., 2004). Obesity can be portrayed as related with an unbalanced rate of Reactive Oxygen Species (ROS) generation contrasted with their expulsion and a chronic inflammatory disease (Gomes et al., 2012). Overweight was identified with an expansion in a free radical production through lipid peroxidation which can have downstream effects on biological functions of the cell (Fernández-Sánchez et al., 2011). Also, the results of the current investigation demonstrated that the total antioxidants (TAS) activity decreased in rats of HFD group, contrasted with control rats and ginger extracted treated rats, showing the decreased capacity of the free radical scavenging in obese animals group and ulterior evolution of oxidative stress. Moreover, different studies, ginger extract when given to obese animals stimulated increased levels of anti-oxidants that are evident by the increased activity of TAS in renal tissue (Furukawa et al., 2017).

Ginger extracts have high levels of polyphenolic and flavonoid compounds with high antioxidant activity (Tohma et al., 2017). The existence of flavonoids and polyphenols in the Z. officinale extract might be responsible for the antioxidant and nephroprotective actions. Several mechanisms were suggested for the effect of ginger components. First, they can prevent synthesis of several proinflammatory cytokines including TNF- $\alpha$ which is the major cytokines, start inflammatory reactions. Second, recent investigations showed that ginger has an influence on some genes including cytokines, the cyclo-oxygenase-2 (COX2) enzyme, and chemokines. In this study, rats in HFD group showed that histological changes including renal fibrosis and tubular necrosis, degenerated epithelial cells, necrotic debris in tubular lumen, pyknotic nuclei and inflammation were 
clearly improved, as well as the reno-protective effect of ginger extract (Nwaopara et al., 2008). The ultrastructural perceptions of the renal sections of HFD group revealed an increase in the glomerular endothelial cells and collagen fibrotic glomerulopathy in the mesangium and the mesangial cells. The enhanced proliferation of the glomerular endothelial cells was included in the pathogenesis of some glomerulopathies as a result of a nephrotoxic insult exposure. In the present investigation, the podocytes villus hypertrophy and foot process effacement were observed. The renal proximal tubules of HFD-treated rats were found to have some pathological modifications, as their brush margin was destructed and irregular in structure. Also, the cytoplasm was found to contain numerous vacuoles, mitochondria with electron-lucent matrix a large number of cytosomes, and lipid droplets. In current results, the focal wrinkling basement membranes, damaged endothelium and mesangial cells, focal sub-endothelial immune deposit, fusion foot processes, a distorted proximal and distal tubules illustrating increase amounts of lysosomes and vacuoles, damaged apical part of epithelial cell and microvilli, mega-mitochondria and irregular pyknotic nuclei were shown (Tanaka et al., 2009). In the current study, GE+HFD group observed clear amendment in the acute renal dysfunction induced by obesity, which is indicated by the highly significant amendment in the renal ultrastructural changes especially foot processes, the proximal and distal tubules with restored their normal brush margin and mitochondria.

\section{CONCLUSION}

In conclusion, ginger seems to impact body weight and composition through three major mechanisms: heat production increases the breakdown of fat in adipose tissue and reduces absorption of dietary fat in the intestine. Thus, $\mathrm{GE}$ is a promising agent for the avoidance of HFD-initiated reno-toxicity in obese animals.

ACKNOWLEDGEMENTS. The authors thank Deanship of Scientific Research, Princess Nourah bint Abdulrahman University, Saudi Arabia, for the financial support to complete this study (Grant No. 162/37).

BIN-MEFERIJ, M. M.; EL-KOTT, A. F. \& SHATI, A. \& EID, R. A. El extracto de jengibre mejora el daño renal en la obesidad inducida por la dieta alta en grasas en ratas: Estudio bioquímico y ultraestructural. Int. J. Morphol., 37(2):438-447, 2019.

RESUMEN: La obesidad es un factor de riesgo modificable para el desarrollo y la progresión de la enfermedad renal. La obesidad puede dañar los riñones en personas sin hipertensión, diabetes o enfermedad renal preexistente. El jengibre, Zingiber officinale, tiene muchos beneficios farmacéuticos. Este estudio tuvo como objetivo evaluar el efecto protector de Zingiber officinale en las complicaciones de la obesidad inducida por una dieta alta en grasas y las enfermedad renal. El período de estudio fue de dos meses, y los grupos de animales experimentales fueron cuatro, se asignaron 80 ratas Wistar de manera similar, 20 animales por grupo: grupo de control; grupo de extracto de jengibre (GE); dieta alta en grasas (DAG); y el grupo GE + DAG. Se evaluó el peso corporal y la grasa, creatinina, leptina, TNF- $\alpha$, antioxidantes totales, histopatología renal y ultraestructura. Las ratas en el grupo de DAG mostraron un aumento significativo $(\mathrm{P}<0,05)$ en el peso corporal y de grasa, creatinina, leptina y TNF-a, y una disminución significativa $(\mathrm{P}<0,05)$ en los antioxidantes totales. La administración de jengibre mostró una protección significativa restaurando los parámetros alterados. Además, las ratas tratadas conjuntamente con extracto de jengibre mejoraron la lesión renal histopatológica y ultraestructural inducida por la obesidad. El estudio concluyó que el extracto de jengibre podría suprimir y disminuir el daño renal inducido por la dieta alta en grasas, ya que posee potenciales valores medicinales.

PALABRAS CLAVE: Extracto de jengibre; Histología renal; Dieta alta en grasas; Obesidad, ultraestructural; Leptina; TNF.

\section{REFERENCES}

Adekunle, I. A.; Imafidon, C. E.; Oladele, A. A. \& Ayoka, A. O. Ginger polyphenols attenuate cyclosporine-induced disturbances in kidney function: Potential application in adjuvant transplant therapy. Pathophysiology, 25(2):101-15, 2018.

Ahima, R. S. \& Flier, J. S. Leptin. Annu. Rev. Physiol., 62:413-37, 2000.

Alhashem, F.; Alkhateeb, M.; Sakr, H.; Alshahrani, M.; Alsunaidi, M.; Elrefaey, H.; Alessa, R.; Sarhan, M.; Eleawa, S. M. \& Khalil, M. A. Exercise protects against obesity induced semen abnormalities via downregulating stem cell factor, upregulating Ghrelin and normalizing oxidative stress. EXCLI J., 13:551-72, 2014.

Bancroft, J. D. \& Gamble, M. Theory and Practice of Histological Techniques. 6th ed. London, Churchill Livingstone, 2008.

Bhatt, B. A.; Dube, J. J.; Dedousis, N.; Reider, J. A. \& O’Doherty, R. M. Diet-induced obesity and acute hyperlipidemia reduce IkappaBalpha levels in rat skeletal muscle in a fiber-type dependent manner. Am. J. Physiol. Regul. Integr. Comp. Physiol., 290(1):R233-40, 2006.

Boraska, V.; Rayner, N. W.; Groves, C. J.; Frayling, T. M.; Diakite, M.; Rockett, K. A.; Kwiatkowski, D. P.; Day-Williams, A. G.; McCarthy, M. I. \& Zeggini, E. Large-scale association analysis of TNF/LTA gene region polymorphisms in type 2 diabetes. B. M. C. Med. Genet., 11:69, 2010 .

Câmara, N. O.; Iseki, K.; Kramer, H.; Liu, Z. H. \& Sharma, K. Kidney disease and obesity: epidemiology, mechanisms and treatment. Nat. Rev. Nephrol., 13(3):181-90, 2017.

Chuang, M. H.; Liao, K. M.; Hung, Y. M.; Chou, Y. C. \& Chou, P. Association of TSH elevation with all-cause mortality in elderly patients with chronic kidney disease. PloS One, 12(1):e0168611, 2017.

Ebrahimzadeh Attari, V.; Ostadrahimi, A.; Asghari Jafarabadi, M.; Mehralizadeh, S. \& Mahluji, S. Changes of serum adipocytokines and body weight following Zingiber officinale supplementation in obese women: a RCT. Eur. J. Nutr., 55(6):2129-36, 2016. 
Fernández-Sánchez, A.; Madrigal-Santillán, E.; Bautista, M.; Esquivel-Soto, J.; Morales-González, A.; Esquivel-Chirino, C.; Durante-Montiel, I.; Sánchez-Rivera, G.; Valadez-Vega, C. \& Morales-González, J. A. Inflammation, oxidative stress, and obesity. Int. J. Mol. Sci., 12(5):311732, 2011 .

Furukawa, S.; Fujita, T.; Shimabukuro, M.; Iwaki, M.; Yamada, Y.; Nakajima, Y.; Nakayama, O.; Makishima, M.; Matsuda, M. \& Shimomura, I. Increased oxidative stress in obesity and its impact on metabolic syndrome. J. Clin. Invest., 114(12):1752-61, 2017.

Gomes, E. C.; Silva, A. N. \& de Oliveira, M. R. Oxidants, antioxidants, and the beneficial roles of exercise-induced production of reactive species. Oxid. Med. Cell. Longev., 2012:756132, 2012.

Hatziri, A.; Kalogeropoulou, C.; Xepapadaki, E.; Birli, E.; Karavia, E. A.; Papakosta, E.; Filou, S.; Constantinou, C. \& Kypreos, K. E. Site-specific effects of apolipoprotein E expression on diet-induced obesity and white adipose tissue metabolic activation. Biochim. Biophys. Acta Mol. Basis Dis., 1864(2):471-80, 2018.

Kakimoto, P. A. \& Kowaltowski, A. J. Effects of high fat diets on rodent liver bioenergetics and oxidative imbalance. Redox Biol., 8:216-25, 2016.

Keaver, L.; Webber, L.; Dee, A.; Shiely, F.; Marsh, T.; Balanda, K. \& Perry, I. J. Application of the UK foresight obesity model in Ireland: the health and economic consequences of projected obesity trends in Ireland. PLoS One, 8(11):e79827, 2013.

Kim, S. O.; Chun, K. S.; Kundu, J. K. \& Surh, Y. J. Inhibitory effects of [6]-gingerol on PMA-induced COX-2 expression and activation of NFkappaB and $\mathrm{p} 38$ MAPK in mouse skin. Biofactors, 21(1-4):27-31, 2004.

Kolsi, R. B. A.; Jardak, N.; Hajkacem, F.; Chaaben, R.; Jribi, I.; Feki, A. E.; Rebai, T.; Jamoussi, K.; Fki, L.; Belghith, H. \& Belghith, K. Antiobesity effect and protection of liver-kidney functions by Codium fragile sulphated polysaccharide on high fat diet induced obese rats. Int. J. Biol. Macromol., 102:119-29, 2017.

Little, M. A.; Bhangal, G.; Smyth, C. L.; Nakada, M. T.; Cook, H. T.; Nourshargh, S. \& Pusey, C. D. Therapeutic effect of anti-TNF-alpha antibodies in an experimental model of anti-neutrophil cytoplasm antibody-associated systemic vasculitis. J. Am. Soc. Nephrol., 17(1):160-9, 2006.

Liu, Y.; Wisniewski, M.; Kennedy, J. F.; Jiang, Y.; Tang, J. \& Liu, J., Chitosan and oligochitosan enhance ginger (Zingiber officinale Roscoe) resistance to rhizome rot caused by Fusarium oxysporum in storage. Carbohydr. Polym., 151:474-9, 2016.

Maharlouei, N.; Tabrizi, R.; Lankarani, K. B.; Rezaianzadeh, A.; Akbari, M.; Kolahdooz, F.; Rahimi, M.; Keneshlou, F. \& Asemi, Z. The effects of ginger intake on weight loss and metabolic profiles among overweight and obese subjects: A systematic review and meta-analysis of randomized controlled trials. Crit. Rev. Food Sci. Nutr., 1-14, 2018.

McCormick, K.; Salcedo, J.; Peck, J. \& Wheeler, A. SPSS statistics for data analysis and visualization. Indianapolis, Wiley, 2017. pp.421-39.

Misawa, K.; Hashizume, K.; Yamamoto, M.; Minegishi, Y.; Hase, T. \& Shimotoyodome, A. Ginger extract prevents high-fat diet-induced obesity in mice via activation of the peroxisome proliferator-activated receptor d pathway. J. Nutr. Biochem., 26(10):1058-67, 2015.

Nammi, S.; Sreemantula, S. \& Roufogalis, B. D. Protective effects of ethanolic extract of Zingiber officinale rhizome on the development of metabolic syndrome in high-fat diet-fed rats. Basic Clin. Pharmacol. Toxicol., 104(5):366-73, 2009.

Navarro, J. F. \& Mora-Fernández, C. The role of TNF-alpha in diabetic nephropathy: pathogenic and therapeutic implications. Cytokine Growth Factor Rev., 17(6):441-50, 2006.

Nwaopara, A. O.; Odike, M. A. C.; Inegbenebor, U.; Nwaopara, S. O. \& Ewere, G. I. A comparative study on the effects of excessive consumption of ginger, clove, red pepper and black pepper on the histology of the kidney. Pak. J. Nutr., 7(2):287-91, 2008.

Plantinga, L. C.; Crews, D. C.; Coresh, J.; Miller, E. R. 3rd; Saran, R.; Yee, J.; Hedgeman, E.; Pavkov, M.; Eberhardt, M. S.; Williams, D. E.; Powe, N. R. \& CDC CKD Surveillance Team. Prevalence of chronic kidney disease in US adults with undiagnosed diabetes or prediabetes. Clin. J. Am. Soc. Nephrol., 5(4):673-82, 2010.

Prakash, U. N. \& Srinivasan, K. Fat digestion and absorption in spicepretreated rats. J. Sci. Food Agric., 92(3):503-10, 2012.

Schanton, M.; Maymó, J. L.; Pérez-Pérez, A.; Sánchez-Margalet, V. \& Varone, C. L. Involvement of leptin in the molecular physiology of the placenta. Reproduction, 155(1):R1-R12, 2018.

Tain, Y. L.; Lin, Y. J.; Sheen, J. M.; Yu, H. R.; Tiao, M. M.; Chen, C. C.; Tsai, C. C.; Huang, L. T. \& Hsu, C. N. High fat diets sex-specifically affect the renal transcriptome and program obesity, kidney injury, and hypertension in the offspring. Nutrients, 9(4):E357, 2017.

Tanaka, M.; Yamada, S.; Iwasaki, Y.; Sugishita, T.; Yonemoto, S.; Tsukamoto, T.; Fukui, S.; Takasu, K. \& Muso, E. Impact of obesity on IgA nephropathy: comparative ultrastructural study between obese and non-obese patients. Nephron Clin. Pract., 112(2):c71-8, 2009.

Tohma, H.; Gülçin, I' .; Bursal, E.; Gören, A. C.; Alwasel, S. H. \& Köksal, E. Antioxidant activity and phenolic compounds of ginger (Zingiber officinale Rosc.) determined by HPLC-MS/MS. J. Food Meas. Charact., 11(2):556-66, 2017.

Wang, J.; Ke, W.; Bao, R.; Hu, X. \& Chen, F. Beneficial effects of ginger Zingiber officinale Roscoe on obesity and metabolic syndrome: a review. Ann. N. Y. Acad. Sci., 1398(1):83-98, 2017.

\author{
Corresponding author: \\ Dr. Refaat Ali Mohammed Eid, Ph.D. \\ Department of Pathology \\ College of Medicine \\ King Khalid University \\ Abha \\ SAUDI ARABIA
}

Email: refaat_eid@yahoo.com

Received: 12-09-2018

Accepted: 27-12-2018 